\title{
Development of Radiogallium-Labeled Peptides for Platelet-Derived Growth Factor Receptor $\beta$ (PDGFR $\beta$ ) Imaging: Influence of Different Linkers
}

\author{
Nurmaya Effendi ${ }^{1,2}(\mathbb{D})$, Kenji Mishiro ${ }^{1}\left(\mathbb{D}\right.$, Kazuhiro Shiba ${ }^{3}\left(\mathbb{D}\right.$, Seigo Kinuya ${ }^{4}$ and Kazuma Ogawa ${ }^{1,5, *(D)}$ \\ 1 Institute for Frontier Science Initiative, Kanazawa University, Kakuma-machi, Kanazawa, \\ Ishikawa 920-1192, Japan; nurmaya82@gmail.com (N.E.); mishiro@p.kanazawa-u.ac.jp (K.M.) \\ 2 Faculty of Pharmacy, Universitas Muslim Indonesia, Urip Sumiharjo KM. 10, Makassar 90-231, Indonesia \\ 3 Advanced Science Research Center, Kanazawa University, Takara-machi 13-1, Kanazawa, \\ Ishikawa 920-8640, Japan; shiba@med.kanazawa-u.ac.jp \\ 4 Department of Nuclear Medicine, Institute of Medical, Pharmaceutical and Health Sciences, \\ Kanazawa University, Takara-machi 13-1, Kanazawa, Ishikawa 920-8641, Japan; \\ kinuya@med.kanazawa-u.ac.jp \\ 5 Graduate School of Medical Sciences, Kanazawa University, Kakuma-machi, Kanazawa, \\ Ishikawa 920-1192, Japan \\ * Correspondence: kogawa@p.kanazawa-u.ac.jp; Tel./Fax: +81-76-234-4460
}

Citation: Effendi, N.; Mishiro, K.; Shiba, K.; Kinuya, S.; Ogawa, K. Development of Radiogallium-Labeled Peptides for Platelet-Derived Growth Factor Receptor $\beta$ (PDGFR $\beta$ ) Imaging: Influence of Different Linkers.

Molecules 2021, 26, 41. https:// dx.doi.org/10.3390/molecules26010041

Academic Editor: Derek J. McPhee Received: 30 November 2020 Accepted: 21 December 2020 Published: 23 December 2020

Publisher's Note: MDPI stays neutral with regard to jurisdictional claims in published maps and institutional affiliations.

Copyright: () 2020 by the authors. Licensee MDPI, Basel, Switzerland. This article is an open access article distributed under the terms and conditions of the Creative Commons Attribution (CC BY) license (https: / creativecommons.org/ licenses/by/4.0/).

\begin{abstract}
The purpose of this study is to develop peptide-based platelet-derived growth factor receptor $\beta$ (PDGFR $\beta$ ) imaging probes and examine the effects of several linkers, namely un-natural amino acids (D-alanine and $\beta$-alanine) and ethylene-glycol (EG), on the properties of Ga-DOTA(linker)-IPLPPPRRPFFK peptides. Seven radiotracers, ${ }^{67}$ Ga-DOTA-(linker)-IPLPPPRRPFFK peptides, were designed, synthesized, and evaluated. The stability and cell uptake in PDGFR $\beta$ positive peptide cells were evaluated in vitro. The biodistribution of $\left[{ }^{67} \mathrm{Ga}\right] \mathrm{Ga}-D O T A-\mathrm{EG}_{2}$-IPLPPPRRPFFK ([ $\left.\left.{ }^{67} \mathrm{Ga}\right] 27\right)$ and $\left[{ }^{67} \mathrm{Ga}\right] \mathrm{Ga}$-DOTA-EG 4 -IPLPPPRRPFFK ([ $\left.\left.{ }^{67} \mathrm{Ga}\right] 28\right)$, which were selected based on in vitro stability in murine plasma and cell uptake rates, were determined in BxPC3-luc-bearing nu/nu mice. Seven ${ }^{67}$ Ga-labeled peptides were successfully synthesized with high radiochemical yields $(>85 \%)$ and purities (>99\%). All evaluated radiotracers were stable in PBS ( $\mathrm{pH} 7.4)$ at $37{ }^{\circ} \mathrm{C}$. However, only $\left[{ }^{67} \mathrm{Ga}\right] 27$ and $\left[{ }^{67} \mathrm{Ga}\right] 28$ remained more than $75 \%$ after incubation in murine plasma at $37^{\circ} \mathrm{C}$ for $1 \mathrm{~h}$. $\left[{ }^{67} \mathrm{Ga}\right] 27$ exhibited the highest BxPC3-luc cell uptake among the prepared radiolabeled peptides. As regards the results of the biodistribution experiments, the tumor-to-blood ratios of [ $\left.{ }^{67} \mathrm{Ga}\right] 27$ and $\left[{ }^{67} \mathrm{Ga}\right] 28$ at $1 \mathrm{~h}$ post-injection were $2.61 \pm 0.75$ and $2.05 \pm 0.77$, respectively. Co-injection of $\left[{ }^{67} \mathrm{Ga}\right] 27$ and an excess amount of IPLPPPRRPFFK peptide as a blocking agent can significantly decrease this ratio. However, tumor accumulation was not considered sufficient. Therefore, further probe modification is required to assess tumor accumulation for in vivo imaging.
\end{abstract}

Keywords: PDGFR $\beta$; peptide; imaging

\section{Introduction}

Platelet-derived growth factor receptor beta $(\mathrm{PDGFR} \beta)$ is a protein that forms part of a family of transmembrane receptor tyrosine kinases [1]. PDGFR $\beta$ is overexpressed in numerous human cancer types, including colon [2], breast [3], and pancreatic cancer [4]. The overexpression of PDGFR $\beta$ has been associated with tumor progression features such as cell migration, metastasis, angiogenesis, and proliferation [5-7]. PDGFR $\beta$ is therefore one of the preferred molecular targets for diagnosis and therapy in clinical oncology. PDGFR $\beta$-targeted imaging agents, which are radiolabeled probes using several types of carrier molecules with a high affinity for PDGFR $\beta$, such as PDGF ligand protein [8,9], aptamer [10], affibody molecules [11,12], and peptides [13,14] have been reported. Previously, we explored radioiodinated and radiobrominated quinoline derivatives as probes targeting 
the ATP binding site of PDGFR $\beta$ [15-17]. These radiolabeled probes determined a high affinity for PDGFR $\beta$ and a sufficient level of stability. However, the tumor accumulations of the radiolabeled probes were low, which suggests the requirement of other potential PDGFR $\beta$-targeted radiopharmaceuticals.

Because of their distinctive chemical and biological properties, peptides are attractive carriers when attempting to visualize a molecular target. In addition, the small molecular size of peptides compared to those of antibodies and antibody fragments mean they: can be synthesized, have easily modified structures, have high transitivity into target tissue, show fast blood clearance, and possess less immunogenicity $[18,19]$. Askoxylakis et al. identified linear dodecapeptide IPLPPPSRPFFK (PDGFR-P1) $\left(\mathrm{IC}_{50}=1.4 \mu \mathrm{M}\right)$ targeting PDGFR $\beta$ by the biopanning technique [13]. Marr et al. then developed a PDGFR-P1 derivative, IPLPPPRRPFFK, with higher affinity for PDGFR $\beta\left(\mathrm{IC}_{50}=0.48 \mu \mathrm{M}\right)$ [14]. In this study, we focused on the development of the PDGFR $\beta$-specific peptide (IPLPPPRRPFFK)based radiotracers with ${ }^{68} \mathrm{Ga}$, which is a promising generator produced positron emitter for positron emission tomography (PET), as PDGFR $\beta$ imaging agents. We selected a macrocyclic ligand, 1,4,7,10-tetraazacyclododecane-1,4,7,10-tetraacetic acid (DOTA), as the chelator for ${ }^{68} \mathrm{Ga}$ because it is well known that DOTA is capable of forming a stable complex with gallium [20-23]. Ga-1,4,7-triazacyclononane-1,4,7-triacetic acid (NOTA) complex has the higher stability constant than Ga-DOTA complex [24]. However, we expect that the radiolabeled PDGFR $\beta$-specific peptide will be the applicable to peptide receptor radionuclide therapy (PRRT) with ${ }^{90} \mathrm{Y},{ }^{177} \mathrm{Lu}$, or ${ }^{225} \mathrm{Ac}$ in the future. Thus, we selected DOTA instead of NOTA because DOTA is more suitable for the complexation with these therapeutic radionuclides than NOTA.

However, for some peptides in the DOTA chelation system, which is placed too close to the pharmacophore, the binding affinity may be decreased between peptides and target molecules. In this case, an appropriate spacer insertion between DOTA and the pharmacophore could improve the binding affinity [25-27]. Introduction of linkers can affect both the in vitro and in vivo properties of the peptide toward its molecular target and the corresponding pharmacokinetics [28]. It has been reported that hydrocarbon, un-natural amino acid, and ethylene glycol linkers display profound favorable effects in the receptor binding affinities and/or pharmacokinetics of radiolabeled peptides, such as bombesin, RGD, and $\alpha$-MSH peptides [29-32].

In this study, peptide derivatives with ${ }^{67} \mathrm{Ga}$ were synthesized to determine their viability. PDGFR $\beta$ targeting IPLPPPRRPFFK peptide derivatives radiolabeled with easy-tohandle radioisotope ${ }^{67} \mathrm{Ga}$ have a longer half-life (3.3 days) than ${ }^{68} \mathrm{Ga}\left(\mathrm{t}_{1 / 2}=68 \mathrm{~min}\right)$, and therefore could serve as an alternative radionuclide for research. Moreover, to evaluate the influence of length and types of linkers on IPLPPPRRPFFK peptide properties, the linkersnamely, aaa [(D-alanine $\left.)_{3}\right]$, aaaaa [(D-alanine $\left.)_{5}\right], \beta \beta\left[(\beta \text {-alanine })_{2}\right], \beta \beta \beta \beta\left[(\beta \text {-alanine })_{4}\right]$, $\mathrm{EG}_{2}\left[(\text { ethylene glycol })_{2} \text { ], or } \mathrm{EG}_{4} \text { [(ethylene glycol }\right)_{4}$ ]—were inserted between the IPLPPPRRPFFK peptide $N$-terminus and the Ga-DOTA complex (Figure 1). These linkers have been often used between radiolabeling sites and lead compounds to maintain affinity to targeting receptors because they are: uncharged (electrically neutral), highly stable against enzymatic degradation, and not sterically hindered to preserve the original bioactivity of the pharmacophore [33-35]. Both in vitro and in vivo properties of the radiolabeled IPLPPPRRPFFK derivatives were evaluated. 


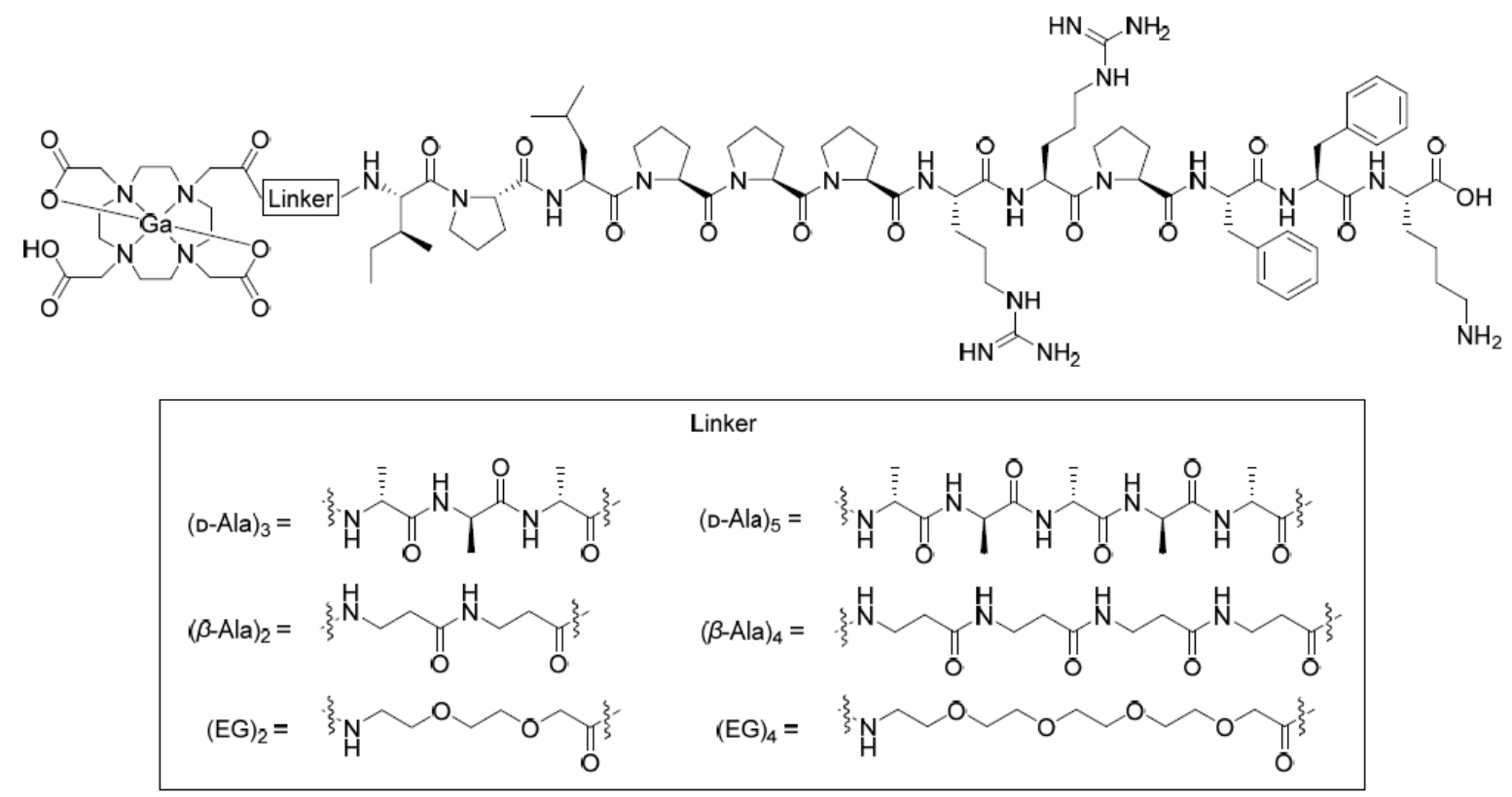

Figure 1. Chemical structures of Ga-DOTA-(linker)-IPLPPPRRPFFK.

\section{Results}

2.1. Synthesis of Precursors and Non-Radiolabeled Compounds

A series of precursors, DOTA-(linker)-IPLPPPRRPFFK (linker = none, aaa, aaaaa, $\left.\beta \beta, \beta \beta \beta \beta, \mathrm{EG}_{2}, \mathrm{EG}_{4}\right)$, were manually prepared using solid-phase peptide synthesis methods with traditional Fmoc chemistry (Scheme 1). The resin-cleaved protected peptides, $\mathrm{H}$-(linker)-IPLPPPR(Pbf)R(Pbf)FFK(Boc), were conjugated with the chelating scaffold DOTA-NHS-ester followed by overall deprotection processes to yield the DOTA-(linker)IPLPPPRRPFFK conjugates in $\sim 45 \%$ yields after RP-HPLC purification. The complexes, ${ }^{n a t}$ Ga-DOTA-(linker)-IPLPPPRRPFFK, were prepared by the reaction between the precursors and gallium nitrate $\left[\mathrm{Ga}\left(\mathrm{NO}_{3}\right)_{3}\right]$ at $40{ }^{\circ} \mathrm{C}$ for $4 \mathrm{~h}$. After RP-HPLC purification, the yields of non-radioactive gallium complexes compounds were $75 \%, 85 \%, 80 \%, 56 \%, 58 \%, 82 \%$, and $81 \%$ for $22, \mathbf{2 3}, \mathbf{2 4}, \mathbf{2 5}, \mathbf{2 6}, \mathbf{2 7}$, and $\mathbf{2 8}$, respectively. The structures of the non-radioactive gallium complexes were confirmed by ESI-MS.

\subsection{Radiolabeling with ${ }^{67} \mathrm{Ga}$}

The radiochemical yields of [ ${ }^{67} \mathrm{Ga}$ ]Ga-DOTA-(linker)-IPLPPPRRPFFK (linker = none, aaa, aaaaa, $\beta \beta, \beta \beta \beta \beta, \mathrm{EG}_{2}$, and $\mathrm{EG}_{4}$ ) were over $85 \%$ (Table 1 ). After purification using RPHPLC, $\left[{ }^{67} \mathrm{Ga}\right] \mathrm{Ga}$-DOTA-(linker)-IPLPPPRRPFFK had a radiochemical purity of over 99\%, as summarized in Table 1 . The identity of [ ${ }^{67} \mathrm{Ga}$ ]Ga-DOTA-(linker)-IPLPPPRRPFFK was confirmed by comparing the retention times with those of the non-radioactive compounds. The comparison showed the same retention times as ${ }^{\text {nat }}$ Ga-DOTA-(linker)-IPLPPPRRPFFK in HPLC chromatograms as seen in Supplementary Figures S1-S7. Precursors and radiometal complexes can be completely separated except $\left[{ }^{67} \mathrm{Ga}\right] 25$ and $\left[{ }^{67} \mathrm{Ga}\right] 26$ by using the isocratic system of RP-HPLC. 


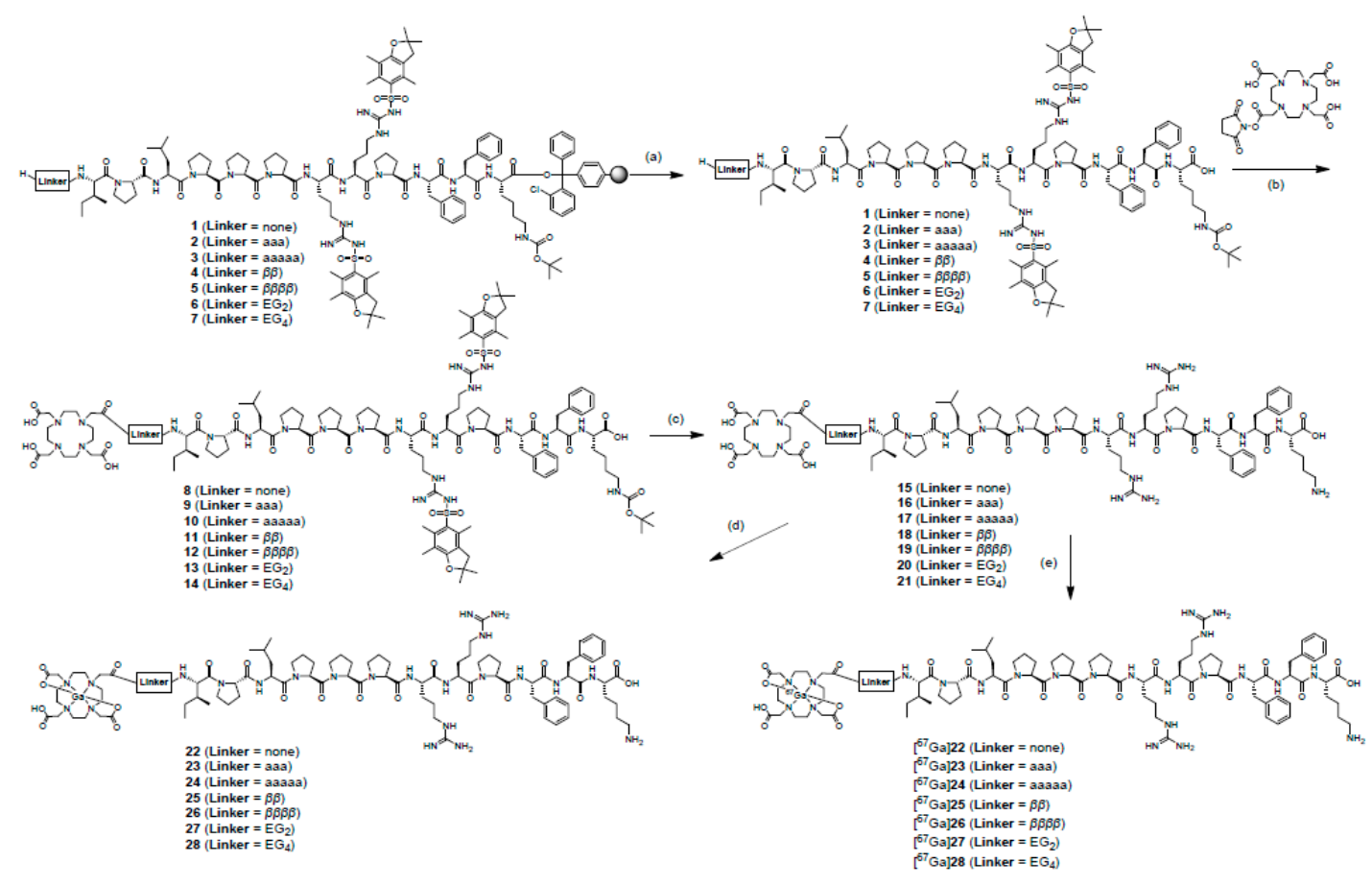

Scheme 1. Syntheses of [ $\left.{ }^{\text {nat } / 67} \mathrm{Ga}\right] \mathrm{Ga}-D O T A-(l i n k e r)-I P L P P P R R F F F K$ (linker = none, aaa, aaaaa, $\beta \beta, \beta \beta \beta \beta, \mathrm{EG}_{2}, \mathrm{EG}_{4}$ ). Reagents and conditions: (a) 30\% HFIP, rt, 5 min; (b) DIPEA, DMF, rt, overnight; (c) 95\% TFA, 2.5\% triisopropylsilane, $2.5 \% \mathrm{H}_{2} \mathrm{O}$, rt, $2 \mathrm{~h}$; (d) $\mathrm{Ga}\left(\mathrm{NO}_{3}\right)_{3}, \mathrm{H}_{2} \mathrm{O}, 40{ }^{\circ} \mathrm{C}, 4 \mathrm{~h}$; (e) $\left[{ }^{67} \mathrm{Ga}\right] \mathrm{GaCl}_{3}, 2 \mathrm{M} \mathrm{HEPES} \mathrm{pH} \mathrm{5.0,85}{ }^{\circ} \mathrm{C}, 10 \mathrm{~min}$.

Table 1. Quality control results for [ $\left.{ }^{67} \mathrm{Ga}\right] \mathrm{Ga}-D O T A-(l i n k e r)-I P L P P P R R P F F K$.

\begin{tabular}{|c|c|c|c|}
\hline \multirow{2}{*}{ Radiopeptides } & \multicolumn{3}{|c|}{ Physical Properties } \\
\hline & RC Yield & RC Purity & $t_{\mathrm{R}}(\min )$ \\
\hline [ $\left.{ }^{67} \mathrm{Ga}\right] \mathrm{Ga}-D O T A-I P L P P P R R P F F K ~\left(\left[{ }^{67} \mathrm{Ga}\right] 22\right)$ & $98.0 \%$ & $99.3 \%$ & 8.5 \\
\hline$\left[{ }^{67} \mathrm{Ga}\right] \mathrm{Ga}-D O T A-a a a-I P L P P P R R P F F K\left(\left[{ }^{67} \mathrm{Ga}\right] 23\right)$ & $86.6 \%$ & $99.5 \%$ & 11.3 \\
\hline$\left[{ }^{67} \mathrm{Ga}\right] \mathrm{Ga}-\mathrm{DOTA}$-aaaaa-IPLPPPRRPFFK $\left(\left[{ }^{67} \mathrm{Ga}\right] 24\right)$ & $94.7 \%$ & $99.3 \%$ & 12.0 \\
\hline$\left[{ }^{67} \mathrm{Ga}\right] \mathrm{Ga}-D O T A-\beta \beta$-IPLPPPRRPFFK $\left(\left[{ }^{67} \mathrm{Ga}\right] 25\right)$ & $97.4 \%$ & $99.1 \%$ & 9.8 \\
\hline$\left[{ }^{67} \mathrm{Ga}\right] \mathrm{Ga}-\mathrm{DOTA}-\beta \beta \beta \beta$-IPLPPPRRPFFK ([$\left.\left.{ }^{67} \mathrm{Ga}\right] 26\right)$ & $97.9 \%$ & $99.6 \%$ & 9.6 \\
\hline$\left[{ }^{67} \mathrm{Ga}\right] \mathrm{Ga}-\mathrm{DOTA}-\mathrm{EG}_{2}-\mathrm{IPLPPPRRPFFK}\left(\left[{ }^{67} \mathrm{Ga}\right] 27\right)$ & $98.1 \%$ & $99.5 \%$ & 12.2 \\
\hline$\left[{ }^{67} \mathrm{Ga}\right] \mathrm{Ga}-\mathrm{DOTA}-\mathrm{EG}_{4}$-IPLPPPRRPFFK ([ $\left.\left.{ }^{67} \mathrm{Ga}\right] 28\right)$ & $96.7 \%$ & $99.4 \%$ & 12.7 \\
\hline
\end{tabular}

HPLC system: Cosmosil 5C 18 -AR-II column (4.6 ID $\times 250 \mathrm{~mm}$; Nacalai Tesque) at a flow rate of $1.0 \mathrm{~mL} / \mathrm{min}$ with a gradient mobile phase of $45-65 \%$ methanol in water with $0.1 \%$ TFA for $20 \mathrm{~min}$, with UV detector at $220 \mathrm{~nm}$ wavelength. RC means radiochemical.

\subsection{In Vitro Stability Experiments}

The radiotracers, ${ }^{67}$ Ga-DOTA-(linker)-IPLPPPRRPFFK peptides, after a $24 \mathrm{~h}$ incubation period at $37^{\circ} \mathrm{C}$ in PBS pH 7.4 showed high stability wherein more than $93 \%$ of radiochemical purities as intact forms. Meanwhile, the radiochemical purities of tracers after incubation were decreased in murine plasma (Table 2).

\subsection{Octanol-Water Partition Coefficient Experiment $(\log P)$}

$\log P$ values for all of radiotracers $\left(\left[{ }^{67} \mathrm{Ga}\right] 22,\left[{ }^{67} \mathrm{Ga}\right] 23,\left[{ }^{67} \mathrm{Ga}\right] 24,\left[{ }^{67} \mathrm{Ga}\right] 25,\left[{ }^{67} \mathrm{Ga}\right] 26\right.$, $\left[{ }^{67} \mathrm{Ga}\right] 27$, or $\left.\left[{ }^{67} \mathrm{Ga}\right] 28\right)$ were less than -4.0 . The data indicate that all of synthesized radiotracers are hydrophilic.

\subsection{In Vitro Cellular Uptake Experiments}

In vitro cellular uptake study could be an index for the binding affinity of radiolabeled compounds to PDGFR $\beta$. Table 3 shows the cellular uptake results of $\left[{ }^{67} \mathrm{Ga}\right] \mathrm{Ga}-\mathrm{DOTA}$ (linker)-IPLPPPRRPFFK (linker = none, aaa, aaaaa, $\beta \beta, \beta \beta \beta \beta, \mathrm{EG}_{2}, \mathrm{EG}_{4}$ ) toward BxPC3-luc 
cells at several observed time points. The highest uptake of $\left[{ }^{67} \mathrm{Ga}\right] 27$ into BxPC3-luc cells was observed. Further evaluation of $\left[{ }^{67} \mathrm{Ga}\right] 27$ and $\left[{ }^{67} \mathrm{Ga}\right] 28$ was performed due to their higher uptake into BxPC3-luc cells and higher stability in murine plasma compared to other tracers. In in vitro blocking studies, uptakes of $\left[{ }^{67} \mathrm{Ga}\right] 27$ and $\left[{ }^{67} \mathrm{Ga}\right] 28$ in BxPC3-luc cells were significantly reduced by pretreatment of excess amounts of IPLPPPRRPFFK (Figure 2).

Table 2. In vitro stability of [ $\left.{ }^{67} \mathrm{Ga}\right] \mathrm{Ga}-\mathrm{DOTA}-($ linker)-IPLPPPRRPFFK in PBS pH 7.4 and murine plasma.

\begin{tabular}{|c|c|c|c|c|}
\hline \multirow{3}{*}{ Radiopeptides } & \multicolumn{4}{|c|}{ In Vitro Stability } \\
\hline & \multicolumn{2}{|c|}{ In PBS pH 7.4} & \multicolumn{2}{|c|}{ In Murine Plasma } \\
\hline & $3 \mathrm{~h}$ & $24 \mathrm{~h}$ & $10 \mathrm{~min}$ & $1 \mathrm{~h}$ \\
\hline$\left[{ }^{67} \mathrm{Ga}\right] \mathrm{Ga}-D O T A-I P L P P P R R P F F K ~\left(\left[{ }^{67} \mathrm{Ga}\right] 22\right)$ & $95.3 \pm 2.7 \%$ & $94.1 \pm 0.6 \%$ & ND & $35.2 \pm 1.7 \%$ \\
\hline$\left[{ }^{67} \mathrm{Ga}\right] \mathrm{Ga}-D O T A-a a a-I P L P P P R R P F F K ~\left(\left[{ }^{67} \mathrm{Ga}\right] 23\right)$ & $95.9 \pm 0.7 \%$ & $94.0 \pm 0.5 \%$ & ND & $15.7 \pm 2.9 \%$ \\
\hline$\left[{ }^{67} \mathrm{Ga}\right] \mathrm{Ga}-D O T A-a a a a a-I P L P P P R R P F F K ~\left(\left[{ }^{67} \mathrm{Ga}\right] 24\right)$ & $96.3 \pm 1.1 \%$ & $94.0 \pm 0.5 \%$ & ND & $41.4 \pm 2.5 \%$ \\
\hline$\left[{ }^{67} \mathrm{Ga}\right] \mathrm{Ga}-D O T A-\beta \beta$-IPLPPPRRPFFK $\left(\left[{ }^{67} \mathrm{Ga}\right] 25\right)$ & $94.2 \pm 1.7 \%$ & $93.0 \pm 0.4 \%$ & ND & $26.2 \pm 6.7 \%$ \\
\hline$\left[{ }^{67} \mathrm{Ga}\right] \mathrm{Ga}-\mathrm{DOTA}-\beta \beta \beta \beta$-IPLPPPRRPFFK ([$\left.\left.{ }^{67} \mathrm{Ga}\right] 26\right)$ & $96.9 \pm 0.3 \%$ & $95.4 \pm 0.2 \%$ & ND & $33.1 \pm 5.7 \%$ \\
\hline$\left[{ }^{67} \mathrm{Ga}\right] \mathrm{Ga}-D O T A-E G_{2}$-IPLPPPRRPFFK $\left(\left[{ }^{67} \mathrm{Ga}\right] 27\right)$ & $96.9 \pm 0.5 \%$ & $95.6 \pm 0.4 \%$ & $84.4 \pm 2.0 \%$ & $75.9 \pm 1.2 \%$ \\
\hline$\left[{ }^{67} \mathrm{Ga}\right] \mathrm{Ga}-\mathrm{DOTA}-\mathrm{EG}_{4}$-IPLPPPRRPFFK $\left(\left[{ }^{67} \mathrm{Ga}\right] 28\right)$ & $96.9 \pm 0.2 \%$ & $94.3 \pm 0.3 \%$ & $96.2 \pm 1.1 \%$ & $80.1 \pm 0.8 \%$ \\
\hline
\end{tabular}

Expressed as percentage of remained intact of radiotracer. Data were presented as the mean (SD) for three samples. ND: not determined.

Table 3. Comparison of the cellular uptake of $\left[{ }^{67} \mathrm{Ga}\right] \mathrm{Ga}$-DOTA-(linker)-IPLPPPRRPFFK (linker = none, aaa, aaaaa, $\beta \beta, \beta \beta \beta \beta$, $\mathrm{EG}_{2}, \mathrm{EG}_{4}$ ) into BxPC3-luc cells.

\begin{tabular}{|c|c|c|c|c|}
\hline \multirow{2}{*}{ Radiopeptides } & \multicolumn{4}{|c|}{ Time Points } \\
\hline & $0.5 \mathrm{~h}$ & $1 \mathrm{~h}$ & $2 \mathrm{~h}$ & $4 \mathrm{~h}$ \\
\hline [ $\left.{ }^{67} \mathrm{Ga}\right] \mathrm{Ga}-D O T A-I P L P P P R R P F F K ~\left(\left[{ }^{67} \mathrm{Ga}\right] 22\right)$ & $0.22(0.03)$ & $0.86(0.24)$ & $0.44(0.10)$ & $0.83(0.16)$ \\
\hline$\left[{ }^{67} \mathrm{Ga}\right] \mathrm{Ga}-D O T A-a a a-I P L P P P R R P F F K ~\left(\left[{ }^{67} \mathrm{Ga}\right] 23\right)$ & $1.40(0.45)$ & $2.07(0.11)$ & $1.89(0.16)$ & $1.07(0.06)$ \\
\hline$\left[{ }^{67} \mathrm{Ga}\right] \mathrm{Ga}-D O T A-a a a a a-I P L P P P R R P F F K ~\left(\left[{ }^{67} \mathrm{Ga}\right] 24\right)$ & $1.40(0.27)$ & $1.85(0.21)$ & $2.55(0.08)$ & $1.28(0.05)$ \\
\hline$\left[{ }^{67} \mathrm{Ga}\right] \mathrm{Ga}-\mathrm{DOTA}-\beta \beta$-IPLPPPRRPFFK $\left(\left[{ }^{67} \mathrm{Ga}\right] 25\right)$ & $0.49(0.18)$ & $0.44(0.05)$ & $0.51(0.09)$ & $0.69(0.13)$ \\
\hline$\left[{ }^{67} \mathrm{Ga}\right] \mathrm{Ga}$-DOTA- $\beta \beta \beta \beta$-IPLPPPRRPFFK $\left(\left[{ }^{67} \mathrm{Ga}\right] 26\right)$ & $0.49(0.13)$ & $0.62(0.10)$ & $0.61(0.22)$ & $0.53(0.02)$ \\
\hline$\left[{ }^{67} \mathrm{Ga}\right] \mathrm{Ga}-D O T A-\mathrm{EG}_{2}-\mathrm{IPLPPPRRPFFK}\left(\left[{ }^{67} \mathrm{Ga}\right] 27\right)$ & $3.09(0.50)$ & $2.98(0.29)$ & $3.70(0.16)$ & $3.35(0.06)$ \\
\hline$\left[{ }^{67} \mathrm{Ga}\right] \mathrm{Ga}-\mathrm{DOTA}-\mathrm{EG}_{4}$-IPLPPPRRPFFK $\left(\left[{ }^{67} \mathrm{Ga}\right] 28\right)$ & $1.29(0.08)$ & $1.37(0.13)$ & $1.09(0.18)$ & $1.72(0.16)$ \\
\hline
\end{tabular}

Expressed as \% dose/mg protein. Data were presented as the mean (SD) for four samples.

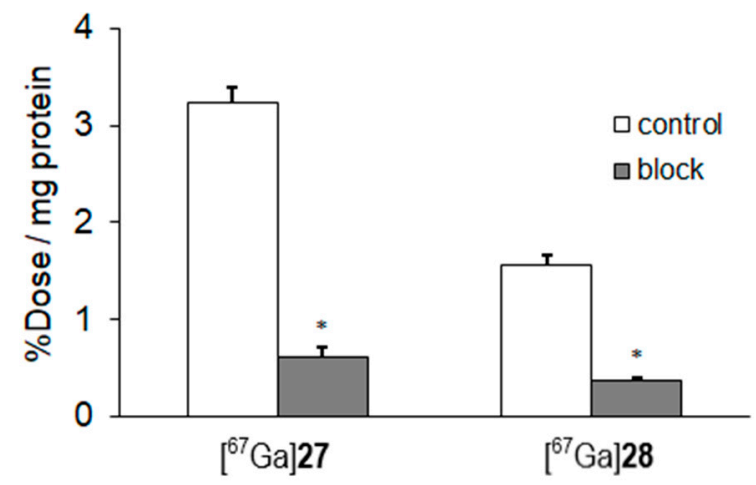

Figure 2. Uptake of $\left[{ }^{67} \mathrm{Ga}\right] 27$ and $\left[{ }^{67} \mathrm{Ga}\right] 28$ into BxPC3-luc cells at $1 \mathrm{~h}$ with or without IPLPPPRRPFFK as a blocking agent. Data were presented as mean \pm SD for three samples. Significance was determined using unpaired Student's $t$-test $\left({ }^{*} p<0.05\right.$, vs. control).

\subsection{Biodistribution Experiments}

The biodistribution of $\left[{ }^{67} \mathrm{Ga}\right] 27$ at $10 \mathrm{~min}$ and $1 \mathrm{~h}$ post-injection, and $\left[{ }^{67} \mathrm{Ga}\right] 28$ at $1 \mathrm{~h}$ post-injection is shown in Table 4 . Although the tumor uptakes of $\left[{ }^{67} \mathrm{Ga}\right] 27$ and $\left[{ }^{67} \mathrm{Ga}\right] 28$ were not high, the tumor-blood ratios of $\left[{ }^{67} \mathrm{Ga}\right] 27$ and $\left[{ }^{67} \mathrm{Ga}\right] 28$ at $1 \mathrm{~h}$ post-injection were 
2.61 and 2.05, respectively. These results are because the blood clearance of radiotracers is so fast. Moreover, the clearance from non-target tissues was also observed to be fast. At $1 \mathrm{~h}$ post-injection, little radioactivity in non-target tissues was seen except in the kidney.

Table 4. Biodistribution of $\left[{ }^{67} \mathrm{Ga}\right] \mathrm{Ga}-\mathrm{DOTA}-\mathrm{EG}_{2}$-IPLPPPRRPFFK $\left(\left[{ }^{67} \mathrm{Ga}\right] 27\right)$ at $10 \mathrm{~min}$ and $1 \mathrm{~h}$ postinjection and $\left[{ }^{67} \mathrm{Ga}\right] \mathrm{Ga}-D O T A-E_{4}$-IPLPPPRRPFFK $\left(\left[{ }^{67} \mathrm{Ga}\right] 28\right)$ at $1 \mathrm{~h}$ after i.v. injection in BxPC3-luc tumor-bearing mice.

\begin{tabular}{ccccccc}
\hline \multirow{2}{*}{ Tissues } & \multicolumn{5}{c}{$\left[{ }^{67} \mathbf{G a}\right] \mathbf{2 7}$} & \multicolumn{1}{c}{$\left[{ }^{67} \mathbf{G a}\right] \mathbf{2 8}$} \\
\cline { 2 - 7 } & $\mathbf{1 0} \mathbf{~ m i n}$ & $\mathbf{1 ~ h}$ & Blocking (1 h) & $\mathbf{1 ~ h}$ \\
\hline Blood & $3.87(0.23)$ & $0.15(0.01)$ & $0.93(0.49)$ & $*$ & $0.12(0.01)$ & $*$ \\
Liver & $0.90(0.01)$ & $0.22(0.06)$ & $0.27(0.04)$ & & $0.20(0.02)$ & \\
Kidney & $13.88(0.49)$ & $3.07(0.55)$ & $12.17(1.04)$ & $*$ & $2.96(0.13)$ & \\
Small intestine & $1.16(0.14)$ & $0.63(0.28)$ & $0.66(0.08)$ & & $0.34(0.33)$ & \\
Large intestine & $0.87(0.18)$ & $0.13(0.04)$ & $0.25(0.01)$ & $*$ & $0.11(0.01)$ & \\
Spleen & $0.99(0.06)$ & $0.13(0.02)$ & $0.29(0.02)$ & $*$ & $0.07(0.01)$ & $*$ \\
Pancreas & $0.89(0.08)$ & $0.13(0.07)$ & $0.21(0.01)$ & & $0.07(0.01)$ & \\
Lung & $3.70(0.11)$ & $0.46(0.10)$ & $0.66(0.05)$ & $*$ & $0.18(0.00)$ & $*$ \\
Heart & $1.47(0.47)$ & $0.07(0.02)$ & $0.28(0.03)$ & $*$ & $0.03(0.00)$ & $*$ \\
Stomach ${ }^{+}$ & $0.19(0.05)$ & $0.06(0.04)$ & $0.05(0.00)$ & & $0.01(0.00)$ & \\
Bone & $1.62(0.30)$ & $0.24(0.06)$ & $0.21(0.02)$ & & $0.10(0.02)$ & $*$ \\
Muscle & $0.86(0.08)$ & $0.07(0.02)$ & $0.22(0.04)$ & $*$ & $0.03(0.00)$ & $*$ \\
Brain & $0.13(0.05)$ & $0.01(0.00)$ & $0.02(0.00)$ & $*$ & $0.00(0.00)$ & $*$ \\
Tumor & $3.11(0.31)$ & $0.39(0.10)$ & $0.96(0.13)$ & $*$ & $0.25(0.05)$ & $*$ \\
Tumor/Blood $\ddagger$ & $0.81(0.11)$ & $2.61(0.75)$ & $1.19(0.48)$ & $*$ & $2.05(0.77)$ &
\end{tabular}

Data were displayed as \%injected dose/gram tissue. Each value represents mean \pm SD for three, four, or seven tumor-bearing mice. Significance was determined using an unpaired Student's $t$-test $\left({ }^{*} p<0.05 \mathrm{vs}\right.$. $\left.{ }^{67} \mathrm{Ga}\right] 27$ at $1 \mathrm{~h}) .{ }^{\dagger}$ presented as \%ID/tissue; ${ }^{\ddagger}$ presented as tumor to organ ratio.

Detailed results of the blocking studies are shown in Table 4. The blocking agent, an excess amount of IPLPPPRRPFFK peptide, affected the biodistribution of $\left[{ }^{67} \mathrm{Ga}\right] 27$. Radioactivity levels in the blood and kidney of the blocking group significantly increased compared to that in $\left[{ }^{67} \mathrm{Ga}\right] 27$ without the blocking agent. This infers that presence of the peptide might inhibit the excretion of $\left[{ }^{67} \mathrm{Ga}\right] 27$ from the kidney. Radioactivity in the tumor in the blocking group also increased due to the delayed blood clearance, however the tumor-to-blood ratio at $1 \mathrm{~h}$ post-injection was significantly decreased by the co-injection of a blocking agent.

\section{Discussion}

PDGFR $\beta$ expression is highly restricted in normal cells and in turn is upregulated in many tumors in humans. Because of this, PDGFR $\beta$ is one of the targets for cancer treatment and therapy. In nuclear medicine imaging, PDGFR $\beta$ has raised considerable interest as an attractive target in numerous human cancers. Although several single photon emission computed tomography (SPECT) or PET radiotracers have been applied to quantify the amount of PDGFR $\beta$ expression [11,12], none have been successful for clinical use.

To optimize the in vivo pharmacological properties of radiometal-based radiopharmaceuticals, a large variety of different tools, such as chelators, linkers, and bioactive agents, have been used [36]. In this study, the chelator was fixed to DOTA, with several types of linkers between peptide and DOTA introduced. Askoxylakis et al. reported that introducing tyrosine for a radiolabeling site with ${ }^{125 / 131}$ I into the N-terminal of IPLPPPRRPFFK (yIPLPPPRRPFFK; yG2) had a 16-times higher affinity for the PDGFR $\beta$ than IPLPPPSRPFFKY (PDGFR-P1) with tyrosine at the C-terminal $[13,14]$. This result suggests that the C-terminal of the peptide sequence can be crucial for receptor binding. Based on this finding, DOTA was introduced into the $\mathrm{N}$-terminal of the IPLPPPRRPFFK peptide via linkers. 
During the in vitro stability experiments, the ${ }^{67} \mathrm{Ga-DOTA}$ complex conjugated an IPLPPPRRPFFK peptide without the presence of a $\left[{ }^{67} \mathrm{Ga}\right] 22$ linker, showing a radiochemical purity level of $35 \%$ at just $1 \mathrm{~h}$ incubation in plasma. Contradicting our original expectations, the insertion of D-alanine and $\beta$-alanine linkers did not improve the peptide stability levels. However, $\left[{ }^{67} \mathrm{Ga}\right] 27$ and $\left[{ }^{67} \mathrm{Ga}\right] 28$ with ethylene glycol linkers showed better stability levels when in plasma (Table 2). The difference of the structures among all radiotracers is only linker part. Thus, the difference of the stability in plasma could be derived from the difference of the recognition by the enzyme in plasma. The higher stability of [ $\left.{ }^{67} \mathrm{Ga}\right] 27$ and $\left[{ }^{67} \mathrm{Ga}\right] 28$ compared to other radiotracers in plasma may be enough because their blood clearance was observed as fast.

The relatively large size of the Ga-DOTA complex might hinder the affinity of IPLPPPRRPFFK to PDGFR $\beta$. By inserting a linker of appropriate type and length, the peptide should maintain the binding affinity of its lead compound as it is with pharmacophore to PDGFR $\beta$. The proper type and length of the spacer might be different for each compound. These variations suggest a need to optimize these techniques so as to better understand the linker and spacer relationships and influences. Previously, such influences have been studied using other peptide types that target specific receptors such as the GRPr $[37,38]$ and neurotensin receptor [36]. Results from these previous studies have seen the accumulation of radiotracers in targeted tissue increased by lengthening hydrocarbon spacers, where ultimately a length of eight carbons per linker (8-aminooctanoic acid) yielded optimum results $[37,38]$. Meanwhile, the insertion of a four-atom hydrocarbon spacer group $(\beta-$ alanine) restored optimal binding affinity of tracers to neurotensin receptors rather than longer spacers [36]. Notwithstanding these previous results, this study used a variation of linker lengths, in particular an eight-atom linker $(\beta \beta)$, nine-atom linkers (aaa and $\left.\mathrm{EG}_{2}\right)$, 15-atom linkers (aaaaa and $\mathrm{EG}_{4}$ ), and a 16-atom linker $(\beta \beta \beta \beta)$. However, the stability and cell uptake levels of tracers did not vary substantially depending on linker length. Results of cell uptake studies exhibited that radiotracers with D-alanine or EG linkers improved the accumulation in BxPC3-luc cells, which highly express PDGFR $\beta$, compared to [ $\left.{ }^{67} \mathrm{Ga}\right] 22$ without a linker. However, $\beta$-alanine linkers did not increase the accumulation (Table 3 ). These results might be influenced by the difficulty experienced in separating $\left[{ }^{67} \mathrm{Ga}\right] 25$ and $\left[{ }^{67} \mathrm{Ga}\right] 26$ from their precursors, ultimately lowering the specific radioactivity. Namely, the precursor in $\left[{ }^{67} \mathrm{Ga}\right] 25$ or $\left[{ }^{67} \mathrm{Ga}\right] 26$ may decrease its uptake because ${ }^{67} \mathrm{Ga}$-labeled peptide and its precursor competitively bind to PDGFR $\beta$.

Biodistribution experiments of $\left[{ }^{67} \mathrm{Ga}\right] 27$ and $\left[{ }^{67} \mathrm{Ga}\right] 28$ were conducted because of the high uptake of BxPC3-luc cells and good stability levels in murine plasma compared to other tracers. As with the results of biodistribution in tumor-bearing mice, $\left[{ }^{67} \mathrm{Ga}\right] 27$ and $\left[{ }^{67} \mathrm{Ga}\right] 28$ showed a high tumor-to-blood ratio at $1 \mathrm{~h}$ post-injection, with a quick clearance from almost non-target tissues. However, the tumor uptake of $\left[{ }^{67} \mathrm{Ga}\right] 27$ and $\left[{ }^{67} \mathrm{Ga}\right] 28$ could be not sufficient for in vivo imaging. Therefore, the structural modification to improve the tumor uptake would be necessary. For example, the dimerization of the peptide could increase the affinity for the target receptor, and would therefore increase tumor uptake [39-41]. Interaction between the monomeric peptide and the receptor binding site is limited. Conversely, dimeric or multimeric peptide could have multivalent interactions, namely multivalent effects toward the receptor target. These multivalent interactions, which arise from synergistic binding of ligands, can enhance the binding affinity of ligands $[42,43]$. Another strategy is the insertion of a longer PEG as a linker, which could delay the blood clearance rate and increase tumor uptake of the radiotracer $[44,45]$.

\section{Materials and Methods}

\subsection{General}

$\left[{ }^{67} \mathrm{Ga}\right] \mathrm{GaCl}_{3}$ was kindly provided by Nihon Mediphysics Co., Ltd. (Tokyo, Japan). 1,4,7,10-Tetraazacyclododecane-1,4,7,10-tetraacetic acid mono- $N$-hydroxysuccinimide ester (DOTA-NHS ester) was purchased from Macrocylics (Dallas, TX, USA). Fmoc-Lys(Boc)-OH, Fmoc-Phe-OH, Fmoc-Pro-OH, Fmoc-Arg(Pbf)-OH, Fmoc-Leu-OH, Fmoc-Ile-OH, Fmoc-D- 
Ala-OH, Fmoc- $\beta$-Ala-OH, and 2-chlorotrityl chloride resin were purchased from Watanabe Chemical Industries, Ltd. (Hiroshima, Japan). Fmoc-EG $-\mathrm{OH}$ (1-(9H-fluoren-9-yl)-3oxo-2,7,10-trioxa-4-azadodecan-12-oic acid) and Fmoc-EG 4 -OH [1-(9H-fluoren-9-yl)-3-oxo2,7,10,13,16-pentaoxa-4-azaoctadecan-18-oic acid] were purchased from BLD Pharmatech Ltd. (Shanghai, China). 1,3-Diisopropylcarbodiimide (DIPCI) and 1-hydroxybenzotriazole hydrate (HOBt) were purchased from Kokusan Chemical Co., Ltd. (Tokyo, Japan). N,NDiisopropylethylamine (DIPEA) and Bicinchoninic Acid (BCA) Protein Assay Kit were purchased from Nacalai Tesque, Inc (Kyoto, Japan). 1,1,1,3,3,3-Hexafluoro-2-propanol (HFIP) was purchased from Tokyo Chemical Industry Co., Ltd. (Tokyo, Japan). Other chemicals and solvents were reagent grade and used as received. BxPC3-luc pancreatic cell line was purchased from JCRB Cell Bank (Ibaraki, Japan). Electrospray ionization mass spectra (ESI-MS) was obtained with JEOL JMS-T100TD (JEOL Ltd., Tokyo, Japan). Purification was conducted using reversed-phase high-performance liquid chromatography (RP-HPLC) system (Prominence system, Shimadzu, Kyoto, Japan). The radioactivity was measured by an Auto Gamma System ARC-7010B (Hitachi, Ltd., Tokyo, Japan).

\subsection{Synthesis of Precursors}

The peptide-chelator conjugates were synthesized manually using a standard Fmocbased solid-phase methodology according to a previous report with a slight modification (Scheme 1) [46]. The peptide chain (IPLPPPRRPFFK) was constructed according to the cycle consisting of (I) 10 min of Fmoc deprotection with $20 \%$ piperidine in dimethylformamide (DMF) and (II) $1.5 \mathrm{~h}$ coupling of the Fmoc protected amino acid (2.5 equiv.) with DIPCI (2.5 equiv.) and HOBt (2.5 equiv.) in DMF. Each Fmoc deprotection and peptide coupling step was monitored by Kaiser test. The coupling reaction was repeated to obtain Ile-Pro-LeuPro-Pro-Pro-Arg(Pbf)-Arg(Pbf)-Pro-Phe-Phe-Lys(Boc)-Resin (1). The resin-bound peptide was treated with 30\% HFIP in dichloromethane for $5 \mathrm{~min}$ to cleave the bond between the resin and the peptide chain. After filtration, the filtrate was concentrated under reduced pressure. The crude residue Ile-Pro-Leu-Pro-Pro-Pro-Arg(Pbf)-Arg(Pbf)-Pro-PhePhe-Lys(Boc) was used in the following reaction without purification. The peptide (1 equiv.), DOTA-NHS ester (1.5 equiv.), and DIPEA (20 equiv.) were mixed in DMF and stirred at room temperature for overnight to obtain DOTA-Ile-Pro-Leu-Pro-Pro-Pro-Arg(Pbf)$\operatorname{Arg}(\mathrm{Pbf})-\mathrm{Pro}-\mathrm{Phe}-\mathrm{Phe}-\mathrm{Lys}(\mathrm{Boc})(8)$. The protecting groups of peptide chain (8) were cleaved by the treatment with a mixture of trifluoroacetic acid (TFA):water:triisopropylsilane (95:2.5:2.5). After stirring for $2 \mathrm{~h}$, the reaction mixture was concentrated by nitrogen gassing.

The crude DOTA-linker-peptide was purified by RP-HPLC on Cosmosil $5 \mathrm{C}_{18}$-AR-II column (10 ID $\times 250 \mathrm{~mm}$; Nacalai Tesque) at a flow rate of $4.0 \mathrm{~mL} / \mathrm{min}$ with a gradient mobile phase of $40-70 \%$ methanol in water with $0.1 \%$ TFA for 20 min (gradient system). Chromatograms were obtained by monitoring the UV absorption at a wavelength of 220 $\mathrm{nm}$. The fraction containing DOTA-Ile-Pro-Leu-Pro-Pro-Pro-Arg-Arg-Pro-Phe-Phe-Lys (15) was determined by mass spectrometry and collected. The final lyophilized peptide of $\mathbf{1 5}$ was obtained in $66.0 \%$ yield as white solid. Other peptides were synthesized using the same procedure as above.

DOTA-IPLPPPRRPFFK (15), LRMS (ESI+) calcd for $\mathrm{C}_{89} \mathrm{H}_{139} \mathrm{~N}_{23} \mathrm{O}_{20}\left[\mathrm{M}+\mathrm{H}^{+}\right]: m / z=$ 1850.1 , found 1850.3 , yield: $66 \%$.

DOTA-aaa-IPLPPPRRPFFK (16), LRMS (ESI+) calcd for $\mathrm{C}_{98} \mathrm{H}_{154} \mathrm{~N}_{26} \mathrm{O}_{23}\left[\mathrm{M}+\mathrm{H}^{+}\right]$: $m / z=2064.2$ found 2064.6 , yield: $75 \%$.

DOTA-aaaaa-IPLPPPRRPFFK (17), LRMS (ESI+) calcd for $\mathrm{C}_{104} \mathrm{H}_{164} \mathrm{~N}_{28} \mathrm{O}_{25}\left[\mathrm{M}+\mathrm{H}^{+}\right]$: $m / z=2206.2$ found 2206.2 , yield: $79 \%$.

DOTA- $\beta \beta$-IPLPPPRRPFFK (18), LRMS (ESI+) calcd for $\mathrm{C}_{95} \mathrm{H}_{149} \mathrm{~N}_{25} \mathrm{O}_{22}\left[\mathrm{M}+\mathrm{H}^{+}\right]$: $m / z=1993.1$ found 1993.5 , yield: $78 \%$.

DOTA- $\beta \beta \beta \beta$-IPLPPPRRPFFK (19), LRMS (ESI+) calcd for $\mathrm{C}_{101} \mathrm{H}_{159} \mathrm{~N}_{27} \mathrm{O}_{24}\left[\mathrm{M}+\mathrm{H}^{+}\right]$: $m / z=2135.2$ found 2135.8 , yield: $58 \%$.

DOTA-EG 2 -IPLPPPRRPFFK (20), LRMS (ESI+) calcd for $\mathrm{C}_{95} \mathrm{H}_{150} \mathrm{~N}_{24} \mathrm{O}_{23}\left[\mathrm{M}+\mathrm{H}^{+}\right]$: $m / z=1996.1$ found 1996.9, yield: $71 \%$. 
DOTA-EG 4 -IPLPPPRRPFFK (21), LRMS (ESI+) calcd for $\mathrm{C}_{99} \mathrm{H}_{158} \mathrm{~N}_{24} \mathrm{O}_{25}\left[\mathrm{M}+\mathrm{H}^{+}\right]$: $m / z=2098.2$ found 2098.6, yield: $48 \%$.

\subsection{Synthesis of ${ }^{\text {nat }} \mathrm{Ga}$-Complexes}

${ }^{\text {nat }}$ Ga-DOTA-(linker)-IPLPPPRRPFFK $(X=$ linker $)\left(X=0\right.$, aaa, aaaaa, $\beta \beta, \beta \beta \beta \beta, \mathrm{EG}_{2}$, $\mathrm{EG}_{4}$ ) was synthesized using a method described previously with a slight modification [46]. In brief, DOTA-IPLPPPRRPFFK $(\mathbf{1 5}, \mathbf{1 6}, \mathbf{1 7}, \mathbf{1 8}, \mathbf{1 9}, \mathbf{2 0}$, or $\mathbf{2 1}$ ) (1 equiv.) in $50 \mu \mathrm{L}$ of water, and $\mathrm{Ga}\left(\mathrm{NO}_{3}\right)_{3}$ (30 equiv.) in $50 \mu \mathrm{L}$ of water were mixed. The reaction mixture was shaken at 40 ${ }^{\circ} \mathrm{C}$ for $4 \mathrm{~h}$. ${ }^{\text {nat }} \mathrm{Ga}$-DOTA-(linker)-IPLPPPRRPFFK was purified by RP-HPLC on Cosmosil $5 \mathrm{C}_{18}$-AR-II column (10 ID $\times 250 \mathrm{~mm}$; Nacalai Tesque) at a flow rate of $4.0 \mathrm{~mL} / \mathrm{min}$ with a gradient mobile phase of $40 \%$ methanol in water with $0.1 \%$ TFA to $70 \%$ methanol in water with $0.1 \%$ TFA for $20 \mathrm{~min}$. Chromatograms were obtained by monitoring the UV adsorption at a wavelength of $220 \mathrm{~nm}$. The fraction containing desired product was determined by mass spectrometry and collected. The solvent was removed by lyophilization to provide ${ }^{\text {nat }}$ Ga-DOTA-(linker)-IPLPPPRRPFFK as white solid.

${ }^{\text {nat }} \mathrm{Ga}$-DOTA-IPLPPPRRPFFK (22), LRMS (ESI+) calcd for $\mathrm{C}_{89} \mathrm{H}_{137} \mathrm{GaN}_{23} \mathrm{O}_{20}\left[\mathrm{M}+\mathrm{H}^{+}\right]$: $m / z=1918.0$ found 1918.5 , yield: $75 \%$.

${ }^{\text {nat } G a-D O T A-a a a-I P L P P P R R P F F K ~(23), ~ L R M S ~(E S I+) ~ c a l c d ~ f o r ~} \mathrm{C}_{98} \mathrm{H}_{152} \mathrm{GaN}_{26} \mathrm{O}_{23}\left[\mathrm{M}+\mathrm{H}^{+}\right]$: $m / z=2131.1$ found 2131.6, yield: $85 \%$.

${ }^{\text {nat }}$ Ga-DOTA-aaaaa-IPLPPPRRPFFK (24), LRMS (ESI+) calcd for $\mathrm{C}_{104} \mathrm{H}_{162} \mathrm{GaN}_{28} \mathrm{O}_{25}$ $\left[\mathrm{M}+\mathrm{H}^{+}\right]: m / z=2273.2$ found 2273.7, yield: $80 \%$.

${ }^{\text {nat }}$ Ga-DOTA- $\beta \beta$-IPLPPPRRPFFK (25), LRMS (ESI+) calcd for $\mathrm{C}_{95} \mathrm{H}_{147} \mathrm{GaN}_{25} \mathrm{O}_{22}\left[\mathrm{M}+\mathrm{H}^{+}\right]$: $m / z=2060.0$ found 2060.6, yield: $56 \%$.

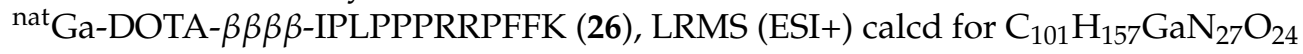
$\left[\mathrm{M}+\mathrm{H}^{+}\right]: m / z=2202.1$ found 2202.6 , yield: $58 \%$.

${ }^{\text {nat }}$ Ga-DOTA-EG - -IPLPPPRRPFFK (27), LRMS (ESI+) calcd for $\mathrm{C}_{95} \mathrm{H}_{148} \mathrm{GaN}_{24} \mathrm{O}_{23}$ $\left[\mathrm{M}+\mathrm{H}^{+}\right]: m / z=2063.0$ found 2063.6, yield: $82 \%$.

${ }^{\text {nat }}$ Ga-DOTA-EG 4 -IPLPPPRRPFFK (28), LRMS (ESI+) calcd for $\mathrm{C}_{100} \mathrm{H}_{158} \mathrm{GaN}_{24} \mathrm{O}_{25}$ $\left[\mathrm{M}+\mathrm{H}^{+}\right]: m / z=2165.1$ found 2165.6 , yield: $81 \%$.

\subsection{Radiolabeling with ${ }^{67} \mathrm{Ga}$}

Radiogallium complexes, $\left[{ }^{67} \mathrm{Ga}\right] \mathrm{Ga}$-DOTA-(linker)-IPLPPPRRPFFK $\left(\left[{ }^{67} \mathrm{Ga}\right] 22,\left[{ }^{67} \mathrm{Ga}\right] \mathbf{2 3}\right.$, $\left[{ }^{67} \mathrm{Ga}\right] 24,\left[{ }^{67} \mathrm{Ga}\right] 25,\left[{ }^{67} \mathrm{Ga}\right] 26,\left[{ }^{67} \mathrm{Ga}\right] 27$, or $\left.\left[{ }^{67} \mathrm{Ga}\right] 28\right)$, were synthesized manually. In detail, an aliquot of $25 \mu \mathrm{g}$ of DOTA-(linker)-IPLPPPRRPFFK was dissolved in $50 \mu \mathrm{L}$ of $0.2 \mathrm{M}$ HEPES buffer ( $\mathrm{pH}$ 5.0). After adding $100 \mu \mathrm{L}$ of $\left[{ }^{67} \mathrm{Ga}\right] \mathrm{GaCl}_{3}$ solution (7.4 MBq in $0.01 \mathrm{M}$ $\mathrm{HCl}$ ), the solution was heated at $85^{\circ} \mathrm{C}$ for $10 \mathrm{~min}$. [ $\left.{ }^{67} \mathrm{Ga}\right] \mathrm{Ga}$-DOTA-(linker)-IPLPPPRRPFFK $\left(\left[{ }^{67} \mathrm{Ga}\right] 22,\left[{ }^{67} \mathrm{Ga}\right] 23,\left[{ }^{67} \mathrm{Ga}\right] 24,\left[{ }^{67} \mathrm{Ga}\right] 25,\left[{ }^{67} \mathrm{Ga}\right] 26,\left[{ }^{67} \mathrm{Ga}\right] 27\right.$, or $\left.\left[{ }^{67} \mathrm{Ga}\right] 28\right)$ was purified by RP-HPLC on Cosmosil 5C 18 -AR-II column (4.6 ID $\times 250 \mathrm{~mm}$; Nacalai Tesque) at a flow rate of $1.0 \mathrm{~mL} / \mathrm{min}$ with an isocratic mobile phase of $46 \%$ methanol in water with $0.1 \%$ TFA for $20 \mathrm{~min}$. Chromatograms were obtained by monitoring the UV adsorption at a wavelength of $220 \mathrm{~nm}$.

\subsection{In Vitro Stability Experiments}

The stability of radiotracers, $\left[{ }^{67} \mathrm{Ga}\right] 22,\left[{ }^{67} \mathrm{Ga}\right] 23,\left[{ }^{67} \mathrm{Ga}\right] 24,\left[{ }^{67} \mathrm{Ga}\right] 25,\left[{ }^{67} \mathrm{Ga}\right] 26,\left[{ }^{67} \mathrm{Ga}\right] 27$, or $\left[{ }^{67} \mathrm{Ga}\right] 28$, in PBS and murine plasma, were analyzed as described previously with a slight modification [47]. Briefly, the solution of radiotracers ( $37 \mathrm{kBq} /$ well, $50 \mu \mathrm{L})$ in a sealed tube containing $0.1 \mathrm{M}$ PBS pH $7.4(450 \mu \mathrm{L})$ was incubated at $37^{\circ} \mathrm{C}$ for $24 \mathrm{~h}$. At 3 and $24 \mathrm{~h}$ after incubation, the purity of radiotracers was analyzed by RP-HPLC. Meanwhile, for stability assay in murine plasma, radiotracers were mixed in murine plasma at a ratio of $1: 10$. After incubation at $37^{\circ} \mathrm{C}$ for $10 \mathrm{~min}$ and $1 \mathrm{~h}$, an equivalent amount of ice-cold acetonitrile was added. After centrifugation at $1000 \times g$ at $4{ }^{\circ} \mathrm{C}$ for $10 \mathrm{~min}$, the supernatant was filtered through a $0.45-\mu \mathrm{m}$ filter followed by analyzing using RP-HPLC as described above. Then, the radiochemical purities were determined. 


\subsection{Octanol-Water Partition Coefficient Experiment ( $\log P)$}

The octanol-water partition coefficients for radiotracers were determined via the assessment of their distribution in $n$-octanol and PBS ( $\mathrm{pH}$ 7.4) using shake-flask method as described previously [48]. Radioactivity of each layer was measured using auto well gamma counter $(n=4)$.

\subsection{In Vitro Cellular Uptake Experiments}

BxPC3-luc was cultured in RPMI 1640 medium containing 10\% fetal bovine serum (FBS) on 6-well culture plates (containing $1 \times 10^{6}$ cells/well) for $24 \mathrm{~h}$ using a humidified atmosphere $\left(5 \% \mathrm{CO}_{2}\right)$ incubator at $37{ }^{\circ} \mathrm{C}$. After removal of medium, a solution of $\left[{ }^{67} \mathrm{Ga}\right] 22$, $\left[{ }^{67} \mathrm{Ga}\right] 23,\left[{ }^{67} \mathrm{Ga}\right] 24,\left[{ }^{67} \mathrm{Ga}\right] 25,\left[{ }^{67} \mathrm{Ga}\right] 26,\left[{ }^{67} \mathrm{Ga}\right] 27$, or $\left[{ }^{67} \mathrm{Ga}\right] 28(7.4 \mathrm{kBq} /$ well $)$ in medium without FBS was added. After incubation for $0.5,1,2$, and $4 \mathrm{~h}$, the medium from each well was removed and the cells were washed twice with ice-cold PBS $(1 \mathrm{~mL})$. The cells were lysed using $1 \mathrm{M} \mathrm{NaOH}$ aqueous solution $(1 \mathrm{~mL})$. Its radioactivity was determined using an auto well gamma counter. The protein amount of cells was quantified using a BCA Protein Assay Kit following the manufacturer's protocol. In detail, to a sample and a fresh set of standard solution, BSA (bovine serum albumin), in the $0.01-1 \mu \mathrm{g} / \mathrm{mL}$ range $(25 \mu \mathrm{L})$ were added $200 \mu \mathrm{L}$ of working reagent (a mixture of 50 portions of reagent $\mathrm{A}$ and 1 portion of reagent B) in a 96-well plate. After incubation under stirring at $37^{\circ} \mathrm{C}$ for $30 \mathrm{~min}$, the absorbance was measured using a plate reader at $540 \mathrm{~nm}$. The protein concentration of samples was determined from calibration plot of BSA. All data were expressed as percent dose per microgram protein (\%dose $/ \mu \mathrm{g}$ protein).

In blocking experiments, $\left[{ }^{67} \mathrm{Ga}\right] 27$ or $\left[{ }^{67} \mathrm{Ga}\right] 28(7.4 \mathrm{kBq} /$ well $)$ in $2 \mathrm{~mL}$ of medium without FBS was added to each well with or without inhibitors (IPLPPPRRPFFK with final concentration $10 \mu \mathrm{M}$ ). After incubation for $1 \mathrm{~h}$, radioactivity and protein concentration were determined using the same method above-mentioned.

\subsection{Biodistribution Experiments}

All animal handling procedures were approved by the Kanazawa University Animal Care Committee. Experiments with animals were conducted in accordance with the Guidelines for the Care and Use of Laboratory Animals of Kanazawa University. The animals were housed with free access to food and water at $23^{\circ} \mathrm{C}$ with a $12 \mathrm{~h} \mathrm{light/dark}$ schedule. Four-week-old female BALB/c nu/nu mice (12-17 g) were purchased from Japan SLC Inc. (Hamamatsu, Japan). The tumor-bearing model was prepared by subcutaneous inoculation of $1 \times 10^{7}$ BxPC3-luc cells into left shoulder of female BALB/c nu/nu mice. The biodistribution experiment was performed approximately $4-5$ weeks post-inoculation.

A saline solution of $\left[{ }^{67} \mathrm{Ga}\right] 27$ or $\left[{ }^{67} \mathrm{Ga}\right] 28(74 \mathrm{kBq}, 100 \mu \mathrm{L})$ was injected intravenously into the tail vein of the mice. The mice were sacrificed at $10 \mathrm{~min}$ post-injection for $\left[{ }^{67} \mathrm{Ga}\right] 27$ and $1 \mathrm{~h}$ post-injection for $\left[{ }^{67} \mathrm{Ga}\right] 27$ or $\left[{ }^{67} \mathrm{Ga}\right] 28$. For in vivo blocking studies, $100 \mu \mathrm{L}$ of a mixed saline solution of $\left[{ }^{67} \mathrm{Ga}\right] 27(74 \mathrm{kBq})$ and IPLPPPRRPFFK peptide $(1 \mathrm{mg} /$ mouse $)$ was injected via tile vein into the tumor-bearing mice. The mice were sacrificed at $1 \mathrm{~h}$ post-injection. Tissues of interest were removed and weighed. The radioactivity of the tissues was determined using an auto well gamma counter, and counts were corrected for background radiation and physical decay during counting. The data were expressed as percent injected dose per gram tissue $(\% \mathrm{ID} / \mathrm{g})$.

\subsection{Statistical Evaluation}

All data were statistically analyzed using GraphPad Prism 5.0 (GraphPad Software, San Diego, CA, USA) and displayed as mean \pm standard deviation (SD). The significance of in vitro and in vivo blocking studies, as well as biodistribution comparison between $\left[{ }^{67} \mathrm{Ga}\right] 27$ and $\left[{ }^{67} \mathrm{Ga}\right] 28$ groups was determined using Student's $t$-test (unpaired, two-tailed). Results were considered statistically significant at $p<0.05$. 


\section{Conclusions}

In this study, we prepared seven radiolabeled IPLPPPRRPFFK peptide-based probes with different lengths and types of linkers in order to visualize PDGFR $\beta$ expression. $\left[{ }^{67} \mathrm{Ga}\right] 27$ and $\left[{ }^{67} \mathrm{Ga}\right] 28$ with EG linkers exhibited better stability in murine plasma and cell uptake levels compared to other synthesized radiotracers. $\left[{ }^{67} \mathrm{Ga}\right] 27$ and $\left[{ }^{67} \mathrm{Ga}\right] 28$ showed high tumor-to-blood ratio at $1 \mathrm{~h}$ post-injection and fast clearance from most non-target tissues in the biodistribution experiments in tumor-bearing mice. However, further structural modification to increase the accumulation of the tracer in the PDGFR $\beta$-positive tumors is necessary for effective in vivo imaging.

Supplementary Materials: The following are available online, Figure S1: The chromatogram of (a) $\left[{ }^{\text {nat }} \mathrm{Ga}\right] 22$ and $\left[{ }^{67} \mathrm{Ga}\right] 22$, Figure S2: The chromatogram of (a) $\left[{ }^{\text {nat }} \mathrm{Ga}\right] 23$ and $\left[{ }^{67} \mathrm{Ga}\right] 23$, Figure S3: The chromatogram of (a) $\left[{ }^{\text {nat }} \mathrm{Ga}\right] 24$ and $\left[{ }^{67} \mathrm{Ga}\right] 24$, Figure S4: The chromatogram of (a) $\left[{ }^{\text {nat }} \mathrm{Ga}\right] 25$ and $\left[{ }^{67} \mathrm{Ga}\right] 25$, Figure S5: The chromatogram of (a) $\left[{ }^{\text {nat }} \mathrm{Ga}\right] 26$ and $\left[{ }^{67} \mathrm{Ga}\right] 26$, Figure S6: The chromatogram of (a) $\left[{ }^{\text {nat }} \mathrm{Ga}\right] 27$ and $\left[{ }^{67} \mathrm{Ga}\right] 27$, Figure S7: The chromatogram of (a) $\left[{ }^{\text {nat }} \mathrm{Ga}\right] 28$ and $\left[{ }^{67} \mathrm{Ga}\right] 28$.

Author Contributions: Conceptualization, K.O. and N.E.; methodology, K.O. and N.E.; validation, K.O., N.E., K.M., K.S., and S.K.; formal analysis, K.O., K.M., and N.E.; investigation, N.E.; resources, K.O. and K.S.; writing — original draft preparation, N.E.; writing - review and editing, K.O. and K.M.; supervision, K.O. and K.M. All authors have read and agreed to the published version of the manuscript.

Funding: This research was supported by MEXT KAKENHI, Grant-in-Aid for Early-Career Scientists (20K16722).

Conflicts of Interest: The authors declare no conflict of interest.

Sample Availability: Samples of the synthesized compounds are available from the authors.

\section{References}

1. Yu, J.; Liu, X.-W.; Kim, H.-R.C. Platelet-derived Growth Factor (PDGF) Receptor- $\alpha$-activated c-Jun $\mathrm{NH}_{2}$-terminal Kinase-1 Is Critical for PDGF-induced p21 ${ }^{\text {WAF1/CIP1 }}$ Promoter Activity Independent of p53. J. Biol. Chem. 2003, 278, 49582-49588. [CrossRef] [PubMed]

2. Fujino, S.; Miyoshi, N.; Ohue, M.; Takahashi, Y.; Yasui, M.; Hata, T.; Matsuda, C.; Mizushima, T.; Doki, Y.; Mori, M. Platelet-derived growth factor receptor- $\beta$ gene expression relates to recurrence in colorectal cancer. Oncol. Rep. 2018, 39, 2178-2184. [CrossRef] [PubMed]

3. Jansson, S.; Aaltonen, K.; Bendahl, P.-O.; Falck, A.-K.; Karlsson, M.; Pietras, K.; Rydén, L. The PDGF pathway in breast cancer is linked to tumour aggressiveness, triple-negative subtype and early recurrence. Breast Cancer Res. Treat. 2018, 169, $231-241$. [CrossRef] [PubMed]

4. Kurahara, H.; Maemura, K.; Mataki, Y.; Sakoda, M.; Shinchi, H.; Natsugoe, S. Impact of p53 and PDGFR- $\beta$ Expression on Metastasis and Prognosis of Patients with Pancreatic Cancer. World J. Surg. 2016, 40, 1977-1984. [CrossRef] [PubMed]

5. Levitzki, A.; Gazit, A. Tyrosine kinase inhibition: An approach to drug development. Science 1995, 267, 1782-1788. [CrossRef]

6. Östman, A. PDGF receptors-mediators of autocrine tumor growth and regulators of tumor vasculature and stroma. Cytokine Growth Factor Rev. 2004, 15, 275-286. [CrossRef]

7. Östman, A.; Heldin, C. PDGF Receptors as Targets in Tumor Treatment. Adv. Cancer Res. 2007, 97, 247-274. [CrossRef]

8. Fretto, L.J.; Snape, A.J.; Tomlinson, J.E.; Seroogy, J.J; Wolf, D.L.; LaRochelle, W.J.; Giese, N.A. Mechanism of platelet-derived growth factor (PDGF) AA, AB, and BB binding to $\alpha$ and $\beta$ PDGF receptor. J. Biol. Chem. 1993, 268, 3625-3631.

9. Maudsley, S.; Zamah, A.M.; Rahman, N.; Blitzer, J.T.; Luttrell, L.M.; Lefkowitz, R.J.; Hall, R.A. Platelet-Derived Growth Factor Receptor Association with $\mathrm{Na}^{+} / \mathrm{H}^{+}$Exchanger Regulatory Factor Potentiates Receptor Activity. Mol. Cell. Biol. 2000, 20, 8352-8363. [CrossRef]

10. Camorani, S.; Esposito, C.L.; Rienzo, A.; Catuogno, S.; Iaboni, M.; Condorelli, G.; De Franciscis, V.; Cerchia, L. Inhibition of Receptor Signaling and of Glioblastoma-derived Tumor Growth by a Novel PDGFR $\beta$ Aptamer. Mol. Ther. 2014, 22, 828-841. [CrossRef]

11. Strand, J.; Varasteh, Z.; Eriksson, O.; Abrahmsen, L.; Orlova, A.; Tolmachev, V. Gallium-68-Labeled Affibody Molecule for PET Imaging of PDGFR $\beta$ Expression in Vivo. Mol. Pharm. 2014, 11, 3957-3964. [CrossRef] [PubMed]

12. Tolmachev, V.; Varasteh, Z.; Honarvar, H.; Hosseinimehr, S.J.; Eriksson, O.; Jonasson, P.; Frejd, F.Y.; Abrahmsen, L.; Orlova, A. Imaging of platelet-derived growth factor receptor beta expression in glioblastoma xenografts using affibody molecule ${ }^{111}$ In-DOTA-Z09591. J. Nucl. Med. 2014, 55, 294-300. [CrossRef] [PubMed]

13. Askoxylakis, V.; Marr, A.; Altmann, A.; Markert, A.; Mier, W.; Debus, J.; Huber, P.E.; Haberkorn, U. Peptide-Based Targeting of the Platelet-Derived Growth Factor Receptor Beta. Mol. Imaging Biol. 2012, 15, 212-221. [CrossRef] 
14. Marr, A.; Nissen, F.; Maisch, D.; Altmann, A.; Rana, S.; Debus, J.; Huber, P.E.; Haberkorn, U.; Askoxylakis, V. Peptide Arrays for Development of PDGFR $\beta$ Affine Molecules. Mol. Imaging Biol. 2013, 15, 391-400. [CrossRef] [PubMed]

15. Effendi, N.; Mishiro, K.; Takarada, T.; Makino, A.; Yamada, D.; Kitamura, Y.; Shiba, K.; Kiyono, Y.; Odani, A.; Ogawa, K. Radiobrominated benzimidazole-quinoline derivatives as Platelet-derived growth factor receptor beta (PDGFR $\beta$ ) imaging probes. Sci. Rep. 2018, 8, 10369. [CrossRef]

16. Effendi, N.; Mishiro, K.; Takarada, T.; Yamada, D.; Nishii, R.; Shiba, K.; Kinuya, S.; Odani, A.; Ogawa, K. Design, synthesis, and biological evaluation of radioiodinated benzo[ $d]$ imidazole-quinoline derivatives for platelet-derived growth factor receptor $\beta$ (PDGFR $\beta$ ) imaging. Bioorg. Med. Chem. 2019, 27, 383-393. [CrossRef] [PubMed]

17. Effendi, N.; Ogawa, K.; Mishiro, K.; Takarada, T.; Yamada, D.; Kitamura, Y.; Shiba, K.; Maeda, T.; Odani, A. Synthesis and evaluation of radioiodinated 1-\{2-[5-(2-methoxyethoxy)-1H-benzo[d]imidazol-1-yl]quinolin-8-yl\}piperidin-4-amine derivatives for platelet-derived growth factor receptor $\beta$ (PDGFR $\beta$ ) imaging. Bioorg. Med. Chem. 2017, 25, 5576-5585. [CrossRef]

18. Fani, M.; Maecke, H.R.; Okarvi, S.M. Radiolabeled Peptides: Valuable Tools for the Detection and Treatment of Cancer. Theranostics 2012, 2, 481-501. [CrossRef]

19. Saw, P.E.; Song, E. Phage display screening of therapeutic peptide for cancer targeting and therapy. Protein Cell 2019, 10, 787-807. [CrossRef]

20. Ogawa, K.; Takai, K.; Kanbara, H.; Kiwada, T.; Kitamura, Y.; Shiba, K.; Odani, A. Preparation and evaluation of a radiogallium complex-conjugated bisphosphonate as a bone scintigraphy agent. Nucl. Med. Biol. 2011, 38, 631-636. [CrossRef]

21. Ogawa, K.; Ishizaki, A.; Takai, K.; Kitamura, Y.; Kiwada, T.; Shiba, K.; Odani, A. Development of Novel Radiogallium-Labeled Bone Imaging Agents Using Oligo-Aspartic Acid Peptides as Carriers. PLoS ONE 2013, 8, e84335. [CrossRef] [PubMed]

22. Ishizaki, A.; Mishiro, K.; Shiba, K.; Hanaoka, H.; Kinuya, S.; Odani, A.; Ogawa, K. Fundamental study of radiogallium-labeled aspartic acid peptides introducing octreotate derivatives. Ann. Nucl. Med. 2019, 33, 244-251. [CrossRef] [PubMed]

23. Ogawa, K.; Ishizaki, A.; Takai, K.; Kitamura, Y.; Makino, A.; Kozaka, T.; Kiyono, Y.; Shiba, K.; Odani, A. Evaluation of GaDOTA-(D-Asp)n as bone imaging agents: D-aspartic acid peptides as carriers to bone. Sci. Rep. 2017, 7, 13971. [CrossRef] [PubMed]

24. Chakravarty, R.; Chakraborty, S.; Dash, A.; Pillai, M.R. Detailed evaluation on the effect of metal ion impurities on complexation of generator eluted ${ }^{68} \mathrm{Ga}$ with different bifunctional chelators. Nucl. Med. Biol. 2013, 40, 197-205. [CrossRef] [PubMed]

25. Garrison, J.C.; Rold, T.L.; Sieckman, G.L.; Naz, F.; Sublett, S.V.; Figueroa, S.D.; Volkert, W.A.; Hoffman, T.J. Evaluation of the Pharmacokinetic Effects of Various Linking Group Using the ${ }^{111}$ In-DOTA-X-BBN(7-14) $\mathrm{NH}_{2}$ Structural Paradigm in a Prostate Cancer Model. Bioconjugate Chem. 2008, 19, 1803-1812. [CrossRef]

26. Lears, K.A.; Ferdani, R.; Liang, K.; Zheleznyak, A.; Andrews, R.; Sherman, C.D.; Achilefu, S.; Anderson, C.J.; Rogers, B.E. In vitro and in vivo evaluation of ${ }^{64} \mathrm{Cu}$-labeled SarAr-bombesin analogs in gastrin-releasing peptide receptor-expressing prostate cancer. J. Nucl. Med. 2011, 52, 470-477. [CrossRef]

27. Strand, J.; Honarvar, H.; Perols, A.; Orlova, A.; Selvaraju, R.K.; Karlström, A.E.; Tolmachev, V. Influence of Macrocyclic Chelators on the Targeting Properties of ${ }^{68}$ Ga-Labeled Synthetic Affibody Molecules: Comparison with ${ }^{111}$ In-Labeled Counterparts. PLoS ONE 2013, 8, e70028. [CrossRef]

28. Siwowska, K.; Haller, S.; Bortoli, F.; Benešová, M.; Groehn, V.; Bernhardt, P.; Schibli, R.; Müller, C. Preclinical Comparison of Albumin-Binding Radiofolates: Impact of Linker Entities on the in Vitro and in Vivo Properties. Mol. Pharm. 2017, 14, 523-532. [CrossRef]

29. Fragogeorgi, E.A.; Zikos, C.; Gourni, E.; Bouziotis, P.; Paravatou-Petsotas, M.; Loudos, G.; Mitsokapas, N.; Xanthopoulos, S.; Mavri-Vavayanni, M.; Livaniou, E.; et al. Spacer site modifications for the improvement of the in vitro and in vivo binding properties of ${ }^{99} \mathrm{~m} \mathrm{Tc}_{\mathrm{N}} \mathrm{N}_{3} \mathrm{~S}-\mathrm{X}-$ bombesin[2-14] derivatives. Bioconjug. Chem. 2009, 20, 856-867. [CrossRef]

30. Miao, Y.; Gallazzi, F.; Guo, H.; Quinn, T.P. ${ }^{111}$ In-Labeled Lactam Bridge-Cyclized $\alpha$-Melanocyte Stimulating Hormone Peptide Analogues for Melanoma Imaging. Bioconjugate Chem. 2008, 19, 539-547. [CrossRef]

31. Wang, L.; Shi, J.; Kim, Y.S.; Zhai, S.; Jia, B.; Zhao, H.; Liu, Z.; Wang, F.; Chen, X.; Liu, S. Improving tumor-targeting capability and pharmacokinetics of ${ }^{99 \mathrm{~m}}$ Tc-labeled cyclic RGD dimers with PEG4 linkers. Mol. Pharm. 2009, 6, 231-245. [CrossRef] [PubMed]

32. Ogawa, K.; Takeda, T.; Yokokawa, M.; Yu, J.; Makino, A.; Kiyono, Y.; Shiba, K.; Kinuya, S.; Odani, A. Comparison of Radioiodineor Radiobromine-Labeled RGD Peptides between Direct and Indirect Labeling Methods. Chem. Pharm. Bull. 2018, 66, 651-659. [CrossRef] [PubMed]

33. Tornesello, A.L.; Buonaguro, L.; Tornesello, M.L.; Buonaguro, F.M. New Insights in the Design of Bioactive Peptides and Chelating Agents for Imaging and Therapy in Oncology. Molecules 2017, 22, 1282. [CrossRef]

34. Aoki, M.; Zhao, S.; Takahashi, K.; Washiyama, K.; Ukon, N.; Tan, C.; Shimoyama, S.; Nishijima, K.-I.; Ogawa, K. Preliminary Evaluation of Astatine-211-Labeled Bombesin Derivatives for Targeted Alpha Therapy. Chem. Pharm. Bull. 2020, 68, 538-545. [CrossRef] [PubMed]

35. Chen, K.; Chen, X. Design and Development of Molecular Imaging Probes. Curr. Top. Med. Chem. 2010, 10, 1227-1236. [CrossRef] [PubMed]

36. Jia, Y.; Shi, W.; Zhou, Z.; Wagh, N.-K.; Fan, W.; Brusnahan, S.-K.; Garrison, J.-C. Evaluation of DOTA-chelated neurotensin analogs with spacer-enhanced biological performance for neurotensin-receptor-1-positive tumor targeting. Nucl. Med. Biol. 2015, 42, 816-823. [CrossRef] [PubMed] 
37. Lane, S.R.; Nanda, P.; Rold, T.L.; Sieckman, G.L.; Figueroa, S.D.; Hoffman, T.J.; Jurisson, S.S.; Smith, C.J. Optimization, biological evaluation and microPET imaging of copper-64-labeled bombesin agonists, $\left[{ }^{64} \mathrm{Cu}-\mathrm{NO} 2 \mathrm{~A}-(\mathrm{X})-\mathrm{BBN}(7-14) \mathrm{NH}_{2}\right]$, in a prostate tumor xenografted mouse model. Nucl. Med. Biol. 2010, 37, 751-761. [CrossRef] [PubMed]

38. Hoffman, T.J.; Gali, H.; Smith, C.J.; Sieckman, G.L.; Hayes, D.L.; Owen, N.K.; Volkert, W.A. Novel series of ${ }^{111}$ In-labeled bombesin analogs as potential radiopharmaceuticals for specific targeting of gastrin-releasing peptide receptors expressed on human prostate cancer cells. J. Nucl. Med. 2003, 44, 823-831.

39. Li, G.; Wang, X.; Zong, S.; Wang, J.; Conti, P.S.; Chen, K. MicroPET Imaging of CD13 Expression Using a ${ }^{64}$ Cu-Labeled Dimeric NGR Peptide Based on Sarcophagine Cage. Mol. Pharm. 2014, 11, 3938-3946. [CrossRef]

40. Liu, S. Radiolabeled Cyclic RGD Peptides as Integrin $\alpha_{\mathrm{v}} \beta_{3}$-Targeted Radiotracers: Maximizing Binding Affinity via Bivalency. Bioconjugate Chem. 2009, 20, 2199-2213. [CrossRef]

41. Zhou, Y. Radiolabeled Cyclic RGD Peptides as Radiotracers for Imaging Tumors and Thrombosis by SPECT. Theranostics 2011, 1, 58-82. [CrossRef] [PubMed]

42. Brabez, N.; Saunders, K.; Nguyen, K.L.; Jayasundera, T.B.M.; Weber, C.; Lynch, R.M.; Chassaing, G.; Lavielle, S.; Hruby, V.J. Multivalent Interactions: Synthesis and Evaluation of Melanotropin Multimers-Tools for Melanoma Targeting. ACS Med. Chem. Lett. 2012, 4, 98-102. [CrossRef] [PubMed]

43. Gestwicki, J.E.; Cairo, C.W.; Strong, L.E.; Oetjen, K.A.; Kiessling, L.L. Influencing Receptor-Ligand Binding Mechanisms with Multivalent Ligand Architecture. J. Am. Chem. Soc. 2002, 124, 14922-14933. [CrossRef] [PubMed]

44. Kapoor, V.; Singh, A.K.; Rogers, B.E.; Thotala, D.; Hallahan, D.E. PEGylated peptide to TIP1 is a novel targeting agent that binds specifically to various cancers in vivo. J. Control. Release 2019, 298, 194-201. [CrossRef]

45. Sun, X.; Li, Y.; Liu, T.; Li, Z.; Zhang, X.; Chen, X. Peptide-based imaging agents for cancer detection. Adv. Drug Deliv. Rev. 2017, 38-51. [CrossRef] [PubMed]

46. Ogawa, K.; Yu, J.; Ishizaki, A.; Yokokawa, M.; Kitamura, M.; Kitamura, Y.; Shiba, K.; Odani, A. Radiogallium Complex-Conjugated Bifunctional Peptides for Detecting Primary Cancer and Bone Metastases Simultaneously. Bioconjugate Chem. 2015, 26, 1561-1570. [CrossRef]

47. Ogawa, K.; Kanbara, H.; Kiyono, Y.; Kitamura, Y.; Kiwada, T.; Kozaka, T.; Kitamura, M.; Mori, T.; Shiba, K.; Odani, A. Development and evaluation of a radiobromine-labeled sigma ligand for tumor imaging. Nucl. Med. Biol. 2013, 40, 445-450. [CrossRef]

48. Ogawa, K.; Mukai, T.; Arano, Y.; Otaka, A.; Ueda, M.; Uehara, T.; Magata, Y.; Hashimoto, K.; Saji, H. Rhemium-186monoaminemonoamidedithiol-conjugated bisphosphonate derivatives for bone pain palliation. Nucl. Med. Biol. 2006, 33, 513-520. [CrossRef] 